\title{
PENCABUTAN HAK MEMILIH DAN DIPILIH DALAM JABATAN PUBLIK TERHADAP NARAPIDANA TINDAK PIDANA KORUPSI
}

\author{
Muhammad Salam Amrullah dan Murpratiwi Syarifuddin
}

Dosen Fakultas Hukum Universitas Andi Djemma

Jl. Sultan Hasanuddin No. 13 Kota Palopo 91911

\begin{abstract}
Revocation of the right to vote and be elected in public office as an additional penalty applied to the defendant allows corruption cases. This research aimed (1) to investigate and analyze the relevance of the annulment of the vote right for the public position election of the corruption prisoners as seen from the perspective of the criminal aims; and (2) to investigate and analyze the factors effecting the annulment of the vote rights for the public positions of the corruption prisoners. The research was conducted in Jakarta city by choosing the institutions relevant to the problem $s$ of this thesis; they were the corruption eradication commission (KPK), Jakarta first thesis instance court, constitutional court, and the supreme court. The method used was the empirical study of the normative law. The nature of the research was descriptive using the primary and secondary data collected from the documents and interview techniques as well as reading the materials related to the exixting problems. The collected data were the analyzed using the qualitative descriptive analysis. The research result revealed that the imposition of the right to vote and to be voted for the public positions as the additional penalty was considered relevant to the purpose of the punishment, I,e. to give retaliation and deterrent effect against the perpetrators of corruption. The law enforcement continued to expect that this additional punishment could prevent further corruption actions in the future. The factors effecting the implementation of the annulment of the right to vote and be voted for the public positions were already stated clearly in the law No. 31 of 1999 about the amendment of the criminal action corruption Jo the law No. 20 of 2001 about the amendment of the law No. 31 of 1999 about the eradication of the corruption criminal action, and the code of criminal law. As for its legal material, the conditions and mechanism of the annulment of the right to vote and be voted for public positions should be stated more clearly.
\end{abstract}

Keywords: additional punishment, annulment of the right to vote, corruption

\section{A. PENDAHULUAN}

Persamaan permasalahan di Negara maju dan berkembang ialah korupsi, maka dari itu dalam Pemberantasan tindak pidana korupsi sangat gencar dilakukan oleh pemerintahnya. Salah satu negara maju di Asia, dalam memberantas tindak pidana korupsi diterapkan penjatuhan pidana mati yang akan dikenakan kepada warga negara yang terbukti melakukan tindak pidana korupsi, walaupun kebanyakan Negara juga menerapkan pidana mati ini. Menariknya, saat Perdana Menteri berpidato kenegaraan 
dan menyampaikan bahwa dia akan menyiapkan 100 peti mati, 99 untuk para koruptor dan satu peti mati lainnya khusus untuk dirinya sendiri jika melakukan tindak pidana korupsi, Ia tak ingin sekadar dipuji oleh sejarah, dan ia pun tak ingin sekedar meraih citra, ia hanya ingin membuktikan bahwa tugas dan tanggungjawabnya sebagai Perdana Menteri mewajibkan dirinya untuk tidak main-main mengemban tugas dan berani mengambil resiko terberat (dibunuh) jika ia pun kelak tergoda melakukan korupsi. Beda halnya di Indonesia ada terobosan baru dibidang hukum dalam penanganan tindak pidana korupsi yaitu pencabutan hak memilih dan dipilih dalam jabatan publik bagi para koruptor yang pertama kali dilakukan oleh jaksa penuntut Komisi Pemberantasan Tindak Pidana Korupsi (yang selanjutnya disebut KPK).

Untuk mendukung tercapainya tujuan itu diperlukan instrumen-instrumen hukum yang tepat, antara lain dengan kebijakan perundang-undangan.Sahetapy (2009), menegaskan bahwa setiap produk hukum perundang-undangan tidak mungkin terlepas dari sumber mana hukum dijiwai, dipersepsikan, dan dalam penjabarannya atau diwujudkan dalam bentuk manifestasinya haruslah bernapaskan Pancasila.

Meski upaya pemberantasan korupsi gencar dilakukan,sampai saat ini belum ada indikasi penurunan tingkat korupsi. Korupsi merupakan masalah multidimensional yang memiliki unsur politik, ekonomi, sosial, dan budaya yang sering melibatkan para elite penguasa, sehingga memberantas korupsi bukanlah perkara mudah, karena korupsi tidak saja terjadi dilembaga eksekutif tetapi telah merambah lembaga legislatif dan yudikatif. Salah satu faktor penyebab sulitnya korupsi diberantas di Indonesia adalah karena berbagai putusan hakim yang mengadili kasus korupsi sudah terasing dari rasa keadilan yang hidup dalam masyarakat (Ali,2005). Sekarang ini ada sebuah terobosan hukum baru yang dilakukanKPK ialah pencabutan hak memilih dan dipilih dalam jabatan publik bagi pelaku koruptor.Mencabut hak memilih dan dipilih ini ini bukan tanpa dasar. Pencabutan hak politik selain diatur dalam Pasal 10 Kitab Undang-Undang Hukum Pidana (yang selanjutnya disebut KUHP) sebagai pidana tambahanjuga tercantum dalam Pasal 18 Undang-undang No. 31 Tahun 1999 Jo. Undang-Undang No. 20 Tahun 2001 tentang Pemberantasan Tindak Pidana Korupsi.

Dalam konsep ilmu hukum, dalam melaksanakan hak manusia dibatasai dengan kepentingan, sementara kepentingan itu selalu saja berbenturan dengan kepentingan 
orang lain, contohnya saja dalam perancangan Undang-Undang (yang selanjutnya disebut UU) oleh anggota dewan yang terhormat, tentunya dalam produk UU yang dihasilkan didalamnya banyak kepentingan, terkhusus kepada kepentingan partai politiknya sendiri, hukum harus berada ditengah, bersikap adil dan penegak hukum harus serius dalam menangani setiap kasus, karena saat ini kebebasan sangat diagung-agungkan yang kita kenal dengan sebutan demokrasi, tapi ingatkah kita jika kebebasan terlalu diagungkan maka yakin saja ketertiban akan hancur, dan sebaliknya jika ketertiban yang diagungkan maka kebebasan akan terkekang. KPK merupakan badan khusus yang dibentuk oleh presiden dan berwenang melakukan pemberantasan tindak pidana korupsi ini ternyata tidak main-main, guna memberikan efek jera terhadap pelaku tindak pidana korupsi (Siahaan, 2013). Ada beberapa terobosan hukum yang dilakukan. Selama lembaga KPK terbentuk, untuk pertama kalinya seorang terdakwa kasus korupsi dituntut pidana tersebut. Meskipun pidana tambahan berupa pencabutan hak memilih dan dipilih dalam jabatan publik sebenarnya bukan pidana baru dalam sistem pemidanaan Indonesia. Hal serupa juga terjadi pada mantan Presiden Partai Keadilan Sejahtera (yang selanjutnya disebut PKS) Luthfi Hasan Ishaaq Dalam putusannya, hukuman Luthfi Hasan Ishaaq diperberat dari 16 tahun menjadi 18 tahun penjara. Disamping itu, Luthfi hasan ishaaq juga diberikan hukuman tambahan berupa pencabutan hak dipilih dalam jabatan publik.

Pasal 10 KUHP mengatur tentang jenis pidana, pidana pokok terdiri dari pidana mati, pidana penjara, pidana kurungan, pidana denda dan pidana tutupan, sedangkan pidana tambahan terdiri dari pencabutan hak-hak tertentu, perampasan barang-barang tertentu, dan pengumuman putusan hakim. Sekarang diterapkan pencabutan hak yaitu hak politik (politicalrihgts). Adapun yang dimaksud hak politik, menurut UUD NRI Tahun 1945, Tap MPR No XVII/MPR/1998 tentang Hak Asasi Manusia, dan UU No 39 Tahun 1999 tentang Hak Asasi Manusia, ialah hak untuk ikut serta dalam pemerintahan, hak dipilih dan memilih dalam pemilu, dan hak mendirikan partai politik. Karena itu, pencabutan hak politik koruptor berarti menghilangkan hak-hak tersebut sebagai konsekuensi logis atas tindak pidana korupsi.

Pencabutan hak memilih dan dipilih dalam jabatan publik sebagai pidana tambahan memungkinkan diterapkan bagi terdakwa kasus korupsi. Penerapan ini pula 
sangat sesuai dengan semangat pemberantasan korupsi dan langkah pencegahan (preventif) dimana kesempatan untuk melakukan korupsi secara berulang itu di hentikan (Hamzah, 2005). Rasionalisasinya khusus mantan terpidana korupsi sudah pasti tidak akan terlibat lagi untuk meraup uang negara karena tidak memiliki kesempatan atau hak untuk menduduki jabatan publik lagi.Pidana tambahan yang diterapkan sekarang ini mengenai pencabutan hak memilih dan dipilih juga memberikan angin segar bagi proses demokrasi karena kedepan kita tidak akan mendapatkan lagi mantan terpidana korupsi terpilih kembali menjadi anggota legislatif atau kepala daerah. Ini merupakan suatu peristiwa yang memalukan, cacat moral dan mencederai nilai-nilai demokrasi.Tujuan penelitian ini adalah untuk mengetahui dan menganalisis relevansi pencabutan hak memilih dan dipilih dalam jabatan publik terhadap narapidana tindak pidana korupsi dalam perspektif tujuan pemidanaan.

\section{B. METODE PENELITIAN}

Penelitian ini menggunakan metode penelitian hukum yang normatif-empirik, yaitu tipe penelitian yang meneliti tentang produk hukum dan mengaitkannya dengan realita empiris.Spesifikasi penelitian yang digunakan adalah deskriptif analitis untuk memberikan gambaran yang menyeluruh mengenai pencabutan hak memilih dan dipilih dalam jabatan publik terhadap narapidana tindak pidana korupsi dan efektifitasnya. Analisa juga dilakukan dengan mengamati perilaku responden sehubungan dengan pengetahuan tentang peraturan-peraturan hukum, pengetahuan tentang isi peraturan hukum, sikap hukum dan perilaku hukum dalam rangka penegakan hukum.

Jenis dan sumber data yang digunakan untuk mendukung penelitian ini adalah Bahan Hukum Primer, Bahan Hukum Sekunder, Bahan Hukum Tersier. Bahan hukum primer terdiri dari peraturan perundang-undangan, seperti yang terdapat dalam Kitab Undang-Undang Hukum Pidana (KUHP), Undang-undang PTPK, dan beberapa putusan pengadilan atau lembaga negara lainnya yang berkaitan dengan objek penelitian. Bahan hukum sekunder itu diartikan sebagai bahan hukum yang tidak mengikat, tetapi menjelaskan mengenai bahan hukum primer yang merupakan hasil olahan pendapat atau pikiran para pakar atau ahli yang mempelajari suatu bidang tertentu secara khusus yang akan memberikan petunjuk mengenai arah peneliti mengarah. Bahan sekunder dalam hal ini adalah doktrin-doktrin yang ada dalam buku, hasil-hasil penelitian, putusan-putusan 
pengadilan terhadap perkara tindak pidana korupsi, jurnal hukum, internet dan sumbersumber lainnya yang relevan dengan masalah yang diteliti.Bahan hukum tersier adalah bahan hukum yang mendukung bahan primer dan bahan hukum sekunder dengan memberikan pemahaman dan pengertian atas bahan hukum lainnya. Bahan hukum yang dipergunakan adalah kamus hukum.

Pengumpulan data yang digunakan dalam penelitian ini adalahStudi dokumen dan Wawancara.Studi dokumen yaitu melakukan peneitian terhadap dokumen-dokumen yang erat kaitannya dengan masalah penerapan pidana tambahan berupa pencabutan hak memilih dan dipilih dalam jabtan publik terhadap narapidana dan efektifitasnya pada perkara tindak pidana korupsi, guna memperoleh landasan teoritis dan informasi dalam bentuk ketentuan formal serta data melalui dokumen-dokumen resmi yang ada.Wawancara, yaitu pengumpulan data dalam bentuk tanya jawab langsung dengan responden, dalam hal ini hakim yang memutuskan pencabutan hak memilih dan dipilih dalam jabatan publik terhadap narapidana tindak pidana korupsi.

Analisis data yang digunakan adalah analisis data kualitatif sesuai dengan tipe penelitian yang digunakan penulis yaitu normatif empiris. Analisis data kualitatif yaitu data yang terkumpul baik data primer,sekunder, maupun tersier disusun dan dianalisa secara kualitatif dengan menginterpretasikan, menguraikan, menjabarkan dan menyusun secara sistematis logis sesuai dengan tujuan penelitian.

\section{HASIL}

Pencabutan hak memilih dan dipilih dalam jabatan publik, dalam hal ini pencabutan hak memilih itu, merupakan hak konstitusional, Hak-hak warga negara yang tertuang dalam UUD NRI 1945 sebagai konstitusi negara dinamakan hak konstitusional. Setiap warga negara memiliki hak-hak konstitusional sebagaimana yang ada dalam UUD NRI 1945.Sekarang ini ada terobosan baru yang dilakukan oleh jaksa penuntut umum KPK, yaitu pencabutan hak memilih dan dipilih dalam jabatan publik bagi narapidana tindak pidana korupsi, salah satunya terpidana Irjen Djoko Susilo yang dijatuhi hukuman pidana tambahan berupa pencabutan hak memilih dan dipilih dalam jabatan publik. Berbicara mengenai pencabutan hak memilih dan dipilih dalam jabatan publik tentu ada yang setuju dan tidak setuju. Dan setelah penulis melakukan penelitian, menurut hakim 
maupun jaksa yang tidak setuju terhadap pencabutan hak memilih, dan rata-rata dengan alasan yang sama, sebagaimana yang disampaikan oleh Aswanto (salah satu hakim Mahkamah Konstitusi), bahwa "pencabutan hak memilih itu sama saja dengan mencabut hak konstitusional seseorang, jadi itu bertentangan dengan undang-undang".

Setelah penulis juga melakukan wawancara dengan beberapa jaksa yang menuntut pencabutan hak memilih dan dipilih ini, penulis menarik kesimpulan bahwa pada dasarnya jaksa pun juga tidak setuju terhadap pencabutan hak memilihnya, karena itu dapat bertentangan dengan Hak Asasi Manusia, oleh karena itu pada putusan Irjen Djoko Susilo yang dicabut hak memilih dan dipilihnya, jaksa mengadakan review kembali tentang pencabutan hak memilih dan dipilih khususnya hak memilih, dan terbukti bahwa setelah kasus Irjen Djoko Susilo, tidak ada lagi putusan yang ada tuntutan pidana tambahan berupa pencabutan hak memilih dan dipilih, melainkan pencabutan hak dipilih saja.Sebagaimana yang disampaikan salah satu jaksa KPK Yudi kristiana“secara pribadi saya tidak setuju, kalo dicabut haknya untuk memilih, hak memilih itu adalah hak setiap warga Negara, itu merupakan hak konstitusional. tetapi beda halnya ketika, hak untuk dipilih, kalau hak untuk memilih, seberapa banyak jumlah narapidana di indonesia, jumlahnya tidak signifikan, tetapi ketika hak untuk dipilih yang untuk dicabut itulah yang justru signifikan karena, pelaku tipikor biasanya adalah orang-orang yang berpengaruh, orang-orang yang besar, punya panensial support yang tinggi, punya political support yang kuat sehingga dia bisa mempengaruhi oranguntuk memilih yang bersangkutan, maka dari itu saya cenderung bukan hak untuk memilih dan dipilih, kalo hak untuk memilih itu, hak konstitusi, dijamin oleh undang-undang, bahkan cenderung melanggar HAM.

Dengan adanya pendapat-pendapat yang mendukung bahwasanya pencabutan hak memilih itu tidak tepat maka dari itu penulis berpendapat bahwa pencabutan hak memilih untuk diberlakukan, cenderung melanggar Hak Asasi Manusia terpidana untuk memilih apa yang dianggap sebagai tempat untuk meyalurkan aspirasinya dan jika hak memilih yang dicabut maka sangat kecil potensi dari terpidana untuk dapat mengulangi perbuatan korupsi atau penyalahgunaan kekuasaan, karena hak memilih hanyalah hak untuk mengunakan hak pilihnya dalam pemilihan umum atau menyalurkan aspirasi. 
Dalam permasalahan hak dipilih, pada dasarnya sudah benar bahwa pencabutan hak memilih dan dipilih ini diatur dalam undang-undang yaitu dalam UU tindak pidana korupsi dan KUHP, jadi kuat dasar untuk dilakukan pencabutan hak memilih dan dipilih. Dalam hal ini pencabutan hak dipilih ada yang setuju dan ada yang tidak setuju, tetapi tidak sama halnya dengan pencabutan hak memilih, pencabutan hak dipilih ini, setuju dan tidak setujunya terletak pada batas waktu pencabutannya, walupun ada juga yang sama sekali tidak setuju dengan pencabutan hak memilih dan dipih.

Sebagimana yang disampaikan salah satu hakim yang mengadili perkara Irjen Djoko Susilo tingkat PN Suhartoyo yang tidak setuju dengan pencabutan hak memilih dan dipilih“pada kasus Irjen Djoko Susilo saya tidak mengabulkan tuntutan jaksa KPK, yang mengabulkan pidana tambahan berupa pencabutan hak memilih dan dipilih dalam jabatan publik ialah pada tingkat kasasi di Mahkamah Agung, karena menurut saya penjatuhan pidana 10 tahun waktu itu dan uang pengganti, bagi saya itu sudah cukup berat. Dan mengenai pidana tambahan berupa pencabutan hak memilih dan dipilih menurut saya itu akan mendapat penilaian tersendiri dari masyarakat, jadi tanpa dicabut hak memilih dan dipilihnya seorang terpidana korupsi itu pasti akan terseleksi oleh alam, artinya apabila ia akan mencalonkan diri, siapa yang akan memilih orang yang sudah dijatuhi pidana korupsi 10 tahun lebih, jadi intinya akan ada sanksi sosial dari masyarakat."

Berdasarkan wawancara diatas, dapat dijelaskan bahwa bagi kalangan yang tidak setuju dengan pencabutan hak dipilih karena hal tersebut dianggap sebagai suatu sanksi yang berlebihan dan sangat berat dan hal tersebut merupakan penilaian masyarakat apakah akan memilih atau tidak orang yang telah melakukan tindak pidana korupsi yang telah dipidana selama bertahun-tahun. Hal ini bertentangan dengan apa yang disampaikan dari pihak jaksa,pakyudi (jaksa penuntut umum kpk) bahwa,"Pencabutan hak untuk dipilih menurut saya itu pembatasan HAM tetapi tidak melanggar HAM, karena perbuatan korupsi adalah perbuatan cacaat moral, dan saya sebagai jaksa, konsisten bahwa pencabutan hak untuk dipilih dalam jabatan publik sejalan dengan tujuan perindungan hukum. Dan jika kemudian hak memilih irjen djoko susilo itu dicabut hak memilihnya, itu bertentangan, tetapi itu merupakan suatu dinamika yang pada saat itu mengalami discoss dan perdebatan yang cukup panjang mengenai hal 
tersebut, tetapi saya secara pribadi menempatkan diri bahwa bukan pencabutan hak memilih dan dipilih secara keseluruhan, melainkan pencabutan hak untuk dipilih dalam jabatan publik saja."

Bahwa berdasarkan keterangan-keterangan yang diperoleh dari hasil wawancara diatas, penulis berpendapat bahwa pencabutan hak dipilih ini harus dilaksanakan dalam upaya mencegah secara dini seorang terpidana korupsi dapat mengulagi perbuatannya, karena para pelaku korupsi adalah orang-orang yang memiliki kekuatan untuk dapat mempengaruhi dan menggerakkan orang-orang atau pemilih untuk memilihnya dalam jabatan publik sehingga berpotensi melakukan korupsi yang merugikan keuangan negara.

Dengan penjatuhan sanksi pidana tambahan berupa pencabutan hak memilih dan dipilih dalam jabatan publik terhadap pelaku tindak pidana korupsi akan mampu menimbulkan apa yang menjadi tujuan pemidanaan, yaituPembalasan dan Efek jera. Pada dasarnya teori pembalasan dalam tujuan pemidanaan, karena pidana penjara telah merupakan implementasi dari teori pembalasan. Pembalasan yang dimaksud dalam hal ini, terhadap pelaku tindak pidana korupsi yang merupakan kejahatan yang luar biasa (extra ordinary crime) yang penanganannya pun harus luar biasa dengan mendapat hukuman yang seberat-beratnya sesuai dengan tindak pidana korupsi yang dilakukan. Menurut pendapat penulis mengenai tujuan pemidanaan berupa pembalasan, bahwa ketika suatu perbuatan pidana mendapatkan pidana yang berat maka ada kepuasan tersendiri kepada masyarakat yang selama ini dikhianati oleh pelaku koruptor yang telah menyalahgunakan kekuasaannya, dan selain pidana pokok, karena tindak pidana korupsi merupakan kejahatan yang luar biasa maka menurut penulis perlu juga dibalas dengan sanksi pidana tambahan salah satunya dengan dicabutnya hak dipilih dalam jabatan publik.

Teori ini yang memberikan dasar pikiran bahwa dasar hukum dari pidana adalah terletak pada tujuan pidana itu sendiri.Oleh karena pidana itu mempunyai tujuan-tujuan tertentu, maka disamping tujuan lainnya terdapat pula tujuan pokok berupa mempertahankan ketertiban masyarakat(de handhaving der maatshappeljikeorde).Mengenai cara mencapai tujuan itu ada beberapa paham yang merupakan aliran-aliran dari teori tujuan yaitu prevensi khusus dan prevensi 
umum.Prevensi khusus adalah bahwa pencegahan kejahatan melalui pemidanaan dengan maksud mempengaruhi tingkah laku terpidana untuk tidak melakukan tindak pidana lagi.Pengaruhnya ada pada diri terpidana itu sendiri dengan harapan agar terpidana dapat berubah menjadi orang yang lebih baik dan berguna bagi masyarakat.Sedangkan prevensi umum bahwa pengaruh pidana adalah untuk mempengaruhi tingkah laku anggota masyarakat untuk tidak melakukan tindak pidana.

Oleh karena itu penulis berpendapat, Untuk memberikan efek jera serta sebagai usaha preventif, penjatuhan pidana tambahan berupa pencabutan hak memilih dan dipilih dalam jabatan publik adalah salah satu upaya yang tepat, bukan saja untuk kepentingan perekonomian negara namun juga memberikan efek jera kepada para pelaku tindak pidana korupsi secara politi. Relevansi tujuan pemidanaan jika dikaitkan dengan tindak pidana korupsi itu tidak hanya ditujukan kepada orang yang melakukan tindak pidana saja, jadi sejalan dengan tujuan pemidanaan itu, diintegrasikan kalau di dalam teori pemidanaan ada yang dimaksudkan untuk diri dari pelaku ada juga untuk masyarakat, ketika berbicara untuk diri pelaku berarti ada efek penjerahan.

\section{PEMBAHASAN}

Pada penelitian ini menunjukkan bahwa relevansi pencabutan hak dipilih dalam jabatan publik merupakan implementasi dari teori gabungan dalam tujuan pemidanaan berupa pembalasan terhadap perbuatan tindak pidana korupsi,dan tujuan untuk perlindungan tata tertib masyarakat, pidana tambahan berupa pencabutan hak dipilih bertujuan agar menimbulkan efek jera, mencegah orang melakukan tindak pidana korupsi baik secara khusus, yaitu mencegah agar pelaku tidak mengulangi lagi perbuatannya, maupun secara umum, yaitu mencegah orang lain atau umum melakukan tindak pidana korupsi.

Sejak lahirnya NKRI tahun 1945 bangsa ini telah menjunjung tinggi Hak Asasi Manusia (HAM). Sikap tersebut nampak dari Pancasila dan UUD 1945, yang memuat beberapa ketentuan-ketentuan tentang penghormatan HAM warga negara. Sehingga pada praktek penyelenggaraan negara, perlindungan atau penjaminan terhadap HAM dan hak-hak warga Negara (citizen's rights) atau hak-hak constitusional warga Negara (the citizen's constitusional rights) dapat terlaksana. Hak memberikan suara atau memilih (right to vote) merupakan hak dasar (basic right) setiap individu atau warga 
negara yang harus dijamin pemenuhannya oleh Negara. Hak Politik warga Negara mencakup hak untuk memilih dan dipilih, penjamin hak dipilih secara tersurat dalam UUD NRI Tahun 1945 mulai Pasal 27 ayat (1) dan (2); Pasal 28, Pasal 28D ayat (3), Pasal 28E ayat (3), 141. Sementara hak memilih juga diatur dalam Pasal 1 ayat (2), Pasal 2 ayat (1), Pasal 6A (1), Pasal 19 ayat (1) dan Pasal 22C (1) UUD NRI Tahun 1945.142 Perumusan pada Pasal-Pasal tersebut sangat jelas bahwa tidak dibenarkan adanya diskirminasi mengenai ras, kekayaan, agama dan keturunan. Setiap warga negara mempunyai hak yang sama dan implementasinya hak dan kewajiban pun harus bersamasama.

Ketentuan UUD NRI Tahun 1945 di atas mengarahkan bahwa negara harus memenuhi segala bentuk hak asasi setiap warga negaranya, khususnya berkaitan dengan hak politik warga negara dan secara lebih khusus lagi berkaitan dengan hak pilih setiap warga negara dalam Pemilihan Umum di Indonesia. Makna dari ketentuan tersebut menegaskan bahwa segala bentuk produk hukum perundang-undangan yang mengatur tentang Pemilihan Umum khususnya mengatur tentang hak pilih warga negara, seharusnya membuka ruang yang seluas-luasnya bagi setiap warga negara untuk bisa menggunakan hak pilihnya dalam Pemilihan Umum, sebab pembatasan hak pilih warga negara merupakan salah satu bentuk pelanggaran Hak Asasi Manusia.

International Covenant On Civil And Political Rights (ICCPR 1966) berkaitan dengan hak pilih warga negara menegaskan dalam Pasal 25 yang menyebutkan bahwa: "Setiap warga negara harus mempunyai hak dan kesempatan yang sama untuk tanpa pembedaan apapun seperti yang disebutkan dalam Pasal 2 ICCPR dan tanpa pembatasan yang tidak wajar baik untuk berpartisipasi dalam menjalankan segala urusan umum baik secara langsung maupun melalui wakil-wakil yang dipilih secara bebas, selanjutnya untuk memilih dan dipilih pada pemilihan berkala yang bebas dan dengan hak pilih yang sama dan universal serta diadakan melalui pengeluaran suara tertulis dan rahasia yang menjamin para pemilih untuk menyatakan kehendak mereka dengan bebas, dan untuk mendapatkan pelayanan umum di negaranya sendiri pada umumnya atas dasar persamaan (Soekanto, 1988). Ketentuan di atas ditujukan untuk menegaskan bahwa hak pilih merupakan hak asasi. Pembatasan, penyimpangan, peniadaan dan penghapusan hak tersebut merupakan bentuk pelanggaran hak asasi warga negara. 
Undang-Undang No. 39 Tahun 1999 tentang Hak Asasi Manusia yang secara nyata memberikan pengakuan terhadap Hak-hak warga negara yaitu (a) Hak untuk hidup, (b) Hak berkeluarga dan melanjutkan keturunan, (c) Hak mengembangkan diri, (d) Hak memperoleh keadilan, (e) Hak atas kebebasan pribadi, (f) Hak atas rasa aman, (g) Hak atas kesejahteraan, (h) Hak turut serta dalam pemerintahan, (i) Hak wanita, dan (j) Hak anak. Pada point (h) secara nyata Negara memberikan pengakuan kepada setiap warga Negara untuk ikut serta dalam pemerintahan baik dalam hal hak memilih dan dipilih.

Menurut ketentuan Pasal 23 ayat (1) Undang-Undang Nomor 39 Tahun 1999 tentang Hak Asasi Manusia dinyatakan bahwa "Setiap orang bebas untuk memilih dan mempunyai keyakinan politiknya". Lebih lanjut menurut ketentuan Pasal 43 ayat (1) Undang-Undang Nomor 39 Tahun 1999 tentang Hak Asasi Manusia, dinyatakan bahwa "Setiap warga negara berhak untuk dipilih dan memilih dalam pemilihan umum berdasarkan persamaan hak melalui pemungutan suara yang langsung, umum, bebas, rahasia, jujur dan adil sesuai dengan ketentuan peraturan perundang-undangan". Kedua ketentuan Pasal di atas jelas menunjukkan adanya jaminan yuridis yang melekat bagi setiap warga Negara Indonesia itu sendiri untuk melaksanakan hak memilihnya.

Berdasarkan ketentuan Pasal 28 I ayat (2) UUD NRI Tahun 1945, dinyatakan bahwa "Dalam menjalankan hak dan kebebasannya, setiap orang wajib tunduk kepada pembatasan yang ditetapkan dengan Undang-Undang dengan maksud semata-mata untuk menjamin pengakuan serta penghormatan atas hak dan kebebasan orang lain dan untuk memenuhi tuntutan yang adil sesuai dengan pertimbangan moral, nilai-nilai agama, keamanan, dan ketertiban umum dalam suatu masyarakat demokratis". Berdasarkan ketentuan Pasal 28 I ayat(2) jelas menunjukkan bahwa dalam menjalankan hak dan kebebasannya, dimungkinkan adanya pembatasan. Pembatasan yang demikian ini mengacu pada ketentuan Pasal tersebut harus diatur dalam undang-undang, artinya tanpa adanya pengaturan tentang pembatasan tersebut berdasarkan undang-undang maka tidak dimungkinkan dilakukan adanya pembatasan terhadap pelaksanaan hak dan kebebasan yang melekat pada setiap orang dan warga negara Indonesia (Effendy, 2012). Kerangka hukum yang demikian ini perlu untuk dipahami secara bersama dalam rangka memaknai "hak" yang telah diakui dan diatur secara hukum di Indonesia. Kondisi demikian tersebut di atas, apabila mengacu pada ketentuan yang diatur dalam Undang- 
Undang Nomor 39 Tahun 1999 tentang Hak Asasi Manusia, menunjukkan adanya bentuk pelanggaran hukum terhadap jaminan hak memilih yang melekat pada warga negara Indonesia. Adanya ruang untuk melakukan pembatasan terhadap hak yang melekat pada setiap orang dan warga negara Indonesia sebagimana dikemukakan di atas, melahirkan pengaturan bahwa hak memilih tersebut dimungkinkan untuk tidak melekat pada semua warga negara Indonesia. Artinya, hak memilih tersebut diberikan pembatasanpembatasan sehingga warga Negara yang diberikan jaminan untuk memiliki hak memilih tersebut benar-benar merupakan warga negara yang telah memenuhi persyaratan yang telah ditentukan.

\section{E. KESIMPULAN DAN SARAN}

Berdasarkan hasil penelitian dan hasil analisis dapat disimpulkan bahwa relevansi pencabutan hak dipilih dalam jabatan publik merupakan implementasi dari teori gabungan dalam tujuan pemidanaan berupa pembalasan terhadap perbuatan tindak pidana korupsi,dan tujuan untuk perlindungan tata tertib masyarakat, pidana tambahan berupa pencabutan hak dipilih bertujuan agar menimbulkan efek jera, mencegah orang melakukan tindak pidana korupsi baik secara khusus, yaitu mencegah agar pelaku tidak mengulangi lagi perbuatannya, maupun secara umum, yaitu mencegah orang lain atau umum melakukan tindak pidana korupsi. Agar semua lembaga dan aparat penegak hukum menciptakan harmonisasi pemikiran ataupun persamaan persepsi mengenai pencabutan hak memilih dan dipilih dalam jabatan publik agar terobosan baru yang mewujudkan tujuan pemidanaan berupa pembalasan dan tujuan untuk menimbulkan efek jera, tidak hanya digunakan oleh KPK dan di terima di tingkat Mahkamah Agung, sebagai upaya memberantas korupsi dan memaksimalisasi kerugian negara akibat tindak pidana korupsi sehingga terciptanya tujuan pemidanaan yang seharusnya yaitu pembalasan dan efek jera.

\section{DAFTAR PUSTAKA}

AliAchmad. (2005).keterpurukan Hukum di Indonesia (penyebab dan solusinya), Ghalia Indonesia, Bogor.

Effendy Marwan. (2012). Diskresi, Penemuan Hukum, Korporasi \& Tax Amnesty Dalam Penegakan Hukum, Referensi, Jakarta.

Hamzah Andi.(2005). Pemberantasan Korupsi Melalui Hukum Pidana Nasional dan Internasional, Raja Grafindo Persada, Jakarta.

SahetapyJ. E.(2009). Runtuhnya Etik Hukum, Kompas Media Nusantara, Jakarta, SiahaanMonang.(2013).Korupsi Penyakit Sosial Yang Mematikan, PT.Gramedia, Jakarta, 
SoekantoSoerjono. (1988). Efektivitas Hukum dan Penerapan Sanksi (Bandung: CV. Ramadja Karya,)

Undang-Undang Dasar Negara Republik Indonesia Tahun 1945 Pasal 28 J ayat 1 dan 2 Undang-undang No. 31 Tahun 1999 tentang Pemberantasan Tindak Pidana Korupsi Undang-undang No. 20 Tahun 2001 tentang Perubahan atas Undang-undang No. 31 Tahun 1999 tentang Pemberantasan Tindak Pidana Korupsi.

Undang-undang No. 39 Tahun 1999 tentang Hak Asasi Manusia. 